\title{
Revizuire tipografică și opțiune lingvistică în Evanghelia de la Snagov, 1697
}

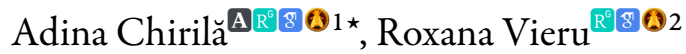 \\ ${ }^{1}$ Facultatea de Litere, Istorie și Teologie, Universitatea de Vest, Bd. Vasile Pârvan 4, 300223 Timişoara, România \\ ${ }^{2}$ Facultatea de Litere, Universitatea „Alexandru Ioan Cuza”, Bd. Carol I 11, 700506 Iași, România
}

\section{Despre articol}

Istoric:

Primit 6 august 2021

Acceptat 8 august 2021

Publicat 18 august 2021

Cuvinte-cheie:

filologie

editarea textelor

analiză comparată

\begin{abstract}
Rezumat
Noua ediție a Evangheliei realizată la Snagov, în 1697 (E 1697) se distinge de cele anterioare ei prin două aspecte: a) organizarea textului - căci se reface și se asigură exactitatea trimiterilor biblice în legătură cu momentele anului bisericesc, făcîndu-se astfel corelarea între cartea liturgică de uz bisericesc și textul-arhetip, Noul Testament, împărțit pe capitole; b) opțiunea lingvistică a diortositorului, care vizează în mod special și consecvent regimul timpurilor verbale, i.e., schimbarea formelor de perfect simplu din ediția-bază (E 1693) în forme de perfect compus.

Diferențe de natură tipografică, de grafie și lingvistice identificate între E 1697 B [ucurești], E 1697 I [ași și E 1697 v[iena], din cele unsprezece exemplare ale cărții păstrate pînă azi, indică desfăşurarea unor etape în realizarea ediției, un comportament editorial și tipografic complex și neliniar.
\end{abstract}

\section{1. $\mathbf{E} 1697$}

Tipografia domnească instalată la Snagov a produs în anul 1697 cinci cărți, dintre care una singură în limba română. Titlul ei integral este $S f[\hat{\imath}]$ nta și $d[u]$ mnezeiasca Evanghelie, cu voia prea luminatului şi înălțatului D[o]mn și oblăduitoriu a toată Țara Rumânească, Io Constandin B. Voievod și cu porunca purtătoriului Pravoslaviei prea sf[i]nțitul Chir Theodosie, Mitropolitul a toatei Țări Rumânești și exarhu plaiurilor. Acum a doa oară tipărită și diortosită, mai cu multă nevoințăa în sf[î̀nta Mănăstire în Sneagov, la anul de la spăseniia lumii 1697, de smeritul intru iermonahi Anthim Ivireanul (Ir) (cf. BRV I, p. 343-344).

Precizarea privind ordinea acestei cărți într-un șir de apariții tipografice similare se referă, probabil, la prima carte cu text românesc la care a lucrat Antim Ivireanul, ca tipograf: Evanghelia greco-română, apărută în 1693 la București, în urma efortului de întocmire depus de Șerban Greceanu și a diortosirii lui Athanasie Moldoveanul.

În fapt, pentru Evanghelia din 1697, Antim Ivireanul a putut avea ca text de bază una din cele două versiuni anterioare: cea din 1682, care, în privința structurii, se îndepărtează de modelul slavon al tetraevanghelului, din secolul anterior, fiind concepută, potrivit predosloviei, „precum umblă cea elinească și întru toate aseamene, după orînduiala Besearecii Răsăritului” (E 1682, [III $\left.{ }^{\mathrm{r}}\right]$ ); și cea bilingvă din 1693, care reia, pe coloana românească, textul anterior, păstrîndu-i organizarea. Întrucît la ediţia din 1693 a lucrat el însuşi, se poate admite că Antim s-a folosit de aceasta în realizarea noii versiuni din 1697, operînd, după cum o sugerează titlul, unele revizuiri; totuşi, colaționarea celor trei ediții relevă situații și diferențe care pot fi explicate numai prin reîntoarcerea diortositorului / tipografului la textul mai vechi, din 1682.

\section{Emendări}

Îndreptările la care se face aluzie în titlul cărții din 1697 au vizat două aspecte: a) structura conținutului și b) forma lingvistică.

\footnotetext{
*Adresă de corespondență: chiriladina@yahoo.com.
} 
Adina Chirilă, Roxana Vieru

În prima privință, a), diferențele dintre E 1697 și E 1693 (și E 1682) sînt, cele mai multe, de detaliu, refăcînd și asigurînd exactitatea în legătură cu momentul respectiv din anul bisericesc și exactitatea trimiterilor biblice. În mod distinct faţă de realizările anterioare ${ }^{1}$, în E 1697 se face corelarea între cartea liturgică de uz bisericesc și textul-arhetip, Noul Testament, împărţit pe capitole:

„Cade-se a ști că la E[va]ng[he]lia aceasta nu s-au pus zacealele pre cum au fost întîi, ce capetele: pentru ca să poată afla fieștecine mai lesne ce i-ar trebui la Tetravanghel. Și pre unde iaste steaoa aceasta [ ], să nu gîndească neștine că s-au pus în toate locuri pentru soroacă de săvîrșit, ce pentru unirea stihurilor den Tetravanghel." (E 1697, [III] $]^{\mathrm{r}}$ ).

Rar, trimiterea spre textul biblic este greșită: în „Luni, a doaosprăzeace săptămînă după Rusalii, de la Matthei, cap. 1" (E 1697, 43 r), pericopa evenghelică utilizată este, în fapt, din Marcu (1,9-15) —o greșeală față de versiunile anterioare E 1693 (94) și E $1682\left(41^{\mathrm{v}}\right)$.

O corectare majoră față de ediția din 1693 o constituie reîntregirea textului cu fragmentele evanghelice corespunzătoare zilelor de luni, marți, miercuri, joi și vineri din a șaptesprezecea săptămînă de după Rusalii a anului bisericesc: în E 1693, „Duminica a 16” este urmată direct de „Sîmbătă a 17” (116); în E 1682, omisiunea nu există $\left(51^{\mathrm{r}}-52^{\mathrm{v}}\right)$. Este neîndoios așadar că Antim se întoarce la sursa inițială cînd apare o nevoie oarecare.

În privinţa formei lingvistice a textului, b), se observă că noul editor a fost preocupat mai ales de regimul timpurilor verbale. Celelalte modificări la nivel gramatical și lexical observate nu vădesc, prin inconsecvența cu care au fost operate, în general, o preocupare deosebită în direcția înnoirii limbii și a expresiei. Face excepție majoră intervenția care vizează schimbarea formelor de perfect simplu din edițiabază (fie ea E 1693, fie E 1682 - diferențele în această privință sînt minime între cele două) în forme de perfect comus. Comparația dintre versiunea din 1697, „diortosită mai cu multă nevoință” $\left(\left[\mathrm{I}^{\mathrm{r}}\right]\right)$, și cea din 1693, pe trei fragmente de text corespondente (v. infra $\left.{ }^{2}\right)$ pune în evidență un demers consecvent în această privință: nu șăzură - nu au șăzut; să sui - s-au suit; găsi - au găsit; scoasă - au scos; răsturnă - au răsturnat etc.

E 1693

Vineri după Paști. De la Ioan. 7 [7]
E 1697

Vineri după Paști, în sărbători, de la Ioann, cap. 2 $\left[3^{\mathrm{v}}-4^{\mathrm{r}}\right]$

În vreamea aceaia veni I[su]s în Capernaum însuşi, și muma lui și frații lui și ucenicii lui; și acolo nu au şezut zile multe. Și era aproape Paștile jidovilor; și s-au suit I [su]s în Ierusalim. Și au găsit în besearecă pre ceia ce vindea boi și oi și porumbi și pre schimbătorii de bani șezînd. Și făcînd bici de ștreanguri, pre toți $i$-au scos den besearecă, oile și boii; și răsipi banii schimbătorilor și measele le-au răsturnat. Și celora ce vindea porumbi le-au zis: „Luați aceastea de aicia și nu faceți casa Tatălui mieu casă de neguțătorie.” Și-ș aduseră aminte ucenicii Lui că iaste scris: „Dragostea casii Tale mă mîncă pre mine.” Răspuns-au jidovii și i-au zis lui: „Ce semn arăț noao, de faci aceastea?”. Răspuns-au I[su]s și le-au zis lor: „Spargeți beseareca aceasta și în trei zile o voiu rădica.” Și ziseră jidovii: „În patruzeci și șase de ani s-au zidit beseareca aceasta și tu în trei zile vei să o rădici?”.

\footnotetext{
${ }^{1}$ Pentru o privire de ansamblu asupra istoriei utilizării Evangheliei la români, v. Pavel (2012, p. 13-28).

${ }^{2}$ În fragmentele prezentate în paralel, formele divergente (perfect simplu vs. perfect compus sau, mai rar, mai-mult-caperfect) sînt culese cu caractere italice.
} 
zicea de beseareca trupului său. Deci cînd să sculă den morți ș-au adus aminte ucenicii lui că aceasta zicea lor și crezură scripturii și cuvîntului carele zisease I $[\mathrm{su}] \mathrm{s}$.

E 1693

Luni, săptămîna a dooa. De la Ioan. 6 [9]

În vreamea aceaia nuntă să făcu în Cana Galileii și era muma lui I[su]s acolo. Şi fu chemat I[su]s şi uc[e]nicii lui la nuntă. Și, sfîrșindu-se vinul, zise muma lui I $[\mathrm{su}] \mathrm{s}$ cătră dînsul: „Vin n-au.” Zise ei I[su]s: „Ce e mie și ție, muiare? Încă n-au venit ceasul mieu." Zise muma lui slugilor: „Orice ar zice voaă, faceți!”. Și era acolo șase vase de piatră, stînd după curățeniia jidovilor, care lua cîte doao sau trei veadre. Zise lor I[su]s: „Umpleți vasele de apă." Și le implură pînă sus. Și zise lor: „Turnați acum și aduceți nunului.” Și-i adusără. Și după ce gustă nunul apa ce să făcuse vin (și nu știia de unde iaste, iară slugile carii turnase apa știia), strigă pre ginere nunul. Și zise lui: „Tot omul întîiu vinul cel bun pune și, deaca să îmbată, atunce cel mai prost. Iară tu ai ținut vinul cel bun pînă acum.” Aceasta fácu începătură seamnelor I $[\mathrm{su}] \mathrm{s}$ în Cana Galileii. Și arătă slava sa și crezură întru el ucenicii lui.

E 1693

$\mathrm{E}[\mathrm{va}] \mathrm{ng}[$ he $]$ lia a opta a sf $[\mathrm{i}]$ ntelor patime. De la Luca. 114 [264-265]

În vreamea aceaia ducea cu I[su]s și alți doi făcători de rău împreună cu el să-i piarză. Și deaca veniră la locul ce să chiamă al Căpăţinii, acolo răstigniră pre el și pre făcătorii de rău: unul de-a direapta și altul de-a stînga. Iară I[su]s zicea: „Părinte, iartă lor, că nu știu ce fac!”. Și împărțind veșmintele lui, puseră sorți. Și sta nărodul privind. Și-ș bătea joc și boiarii împreună cu ei, zicînd: „Pre alții au mîntuit; mîntuiască-se pre sine, de iaste acesta $\mathrm{H}[$ risto $]$ s cel ales al lui D $[\mathrm{u}]$ mnezău." Și-şi bătea joc și slujitorii, apropiindu-să și oțet aducîndu-i lui și zicînd: „De ești tu împăratul jidovilor, mîntuiaşte-te pre tine." Și era și scrisoare scrisă deasupra lui, cu slove ellinești și rîmlenești și jidovești: „Acesta iaste împăratul jidovilor.” Iară unul din cei răstigniți făcători de rău huliia pre dînsul, zicînd: „De ești tu $\mathrm{H}[$ risto]s, mîntuiaște-te pre tine și pre noi!”. Iară răspunzînd celalalt, certa pre el, zicînd: „Nu te temi tu de $\mathrm{D}[\mathrm{u}] \mathrm{mnezău}$, că într-aceaiaș osîndă ești? Și noi, pre direptul, pentru că vreadnice celor ce-am făcut luom; iară acesta nice un rău n-au făcut." Și zicea lui I $[$ su $]$ s: „Pomeneaște-mă, $\mathrm{D}[\mathrm{oa}] \mathrm{mne}$, cînd vei veni întru împărățiia ta!”. Atuncea zise I[su]s lui: „Adevăr zic ție:
Iară El zicea de beseareca trupului său. Deci cînd să sculă den morți ş,-au adus aminte ucenicii că aceasta zicea lor și au crezut scripturii și cuvîntului carele zisease I[su]s.

E 1697

Luni, în săptămîna a dooa după Paști, de la Ioann, cap. $2\left[4^{\mathrm{v}}-5^{\mathrm{r}}\right]$

În vreamea aceaia nuntă s-au faccut în Cana Galileii și era muma lui I[su $]$ s acolo. Și au fost chiemat I[su]s și ucenicii lui la nuntă. Și, sfîrșindu-se vinul, au zis muma lui I[su]s cătră dînsul: „Vin n-au.” Zis-au e <i $>\mathrm{I}[\mathrm{su}] \mathrm{s}$ : „Ce e mie și ție, muiare? Încă n-au venit ceasul mieu." Zis-au muma lui slugilor: „Orice ar zice voao, să faceți!’. Și era acolo șase vase de piatră, puse după curățeniia jidovilor, carele lua cîte doao sau trei veadre. Zis-au lor I[su]s: „Umpleți vasele de apă.” Și le-au umplut pînă sus. Și le-au zis lor: „Turnați acum şi aduceți nunului." Și i-au adus. Și după ce au gustat nunul apa ce să făcuse vin (și nu știia de unde iaste, iară slugile carii turnase apa știia), strigat-au pre ginere nunul. Și i-au zis lui: „Tot omul întii vinul cel bun pune şi, deaca să îmbată, atuncea cel mai prost. Iară tu ai ținut vinul cel bun pînă acum.” Aceasta au făcut începătură seamnelor I $[$ su $]$ s în Cana Galileii. Şi ș-au arătat slava sa și au crezut întru el ucenicii lui.

\section{E 1697}

$\mathrm{E}[\mathrm{va}] \mathrm{ng}[$ he]lia a opta a sf[i]ntelor patime, de la Luca, cap. $23\left[122^{\mathrm{v}}-123^{\mathrm{r}}\right]$

În vreamea aceaia ducea împreună cu I[su]s și alţi doi tîlhari să-i piarză. Și deaca au venit la locul ce să chiamă al Căpăţinilor, acolo l-au răstignit pre el și pre tîlhari: unul de-a direapta și altul de-a stînga. Iară I[su]s zicea: „Părinte, iartă-le lor, că nu știu ce fac!”. Iară cei ce împărțiia hainele lui au aruncat sorți. Și sta norodul de priviia. Și-ș bătea joc de dînsul și boiarii împreună cu dînşii, zicînd: „Pre alții au mîntuit; mîntuiască-se și pre sine, de iaste acesta $\mathrm{H}$ [risto]s cel ales al lui $\mathrm{D}[\mathrm{u}] \mathrm{mnezău}$." Rîdea-ș de el și slujitorii, apropiindu-să și oțet aducîndu-i lui și zicînd: „De ești tu împăratul jidovilor, mîntuiaşte-te pre tine singur." Era și scrisoare scrisă deasupra lui, cu slove ellinești și rîmlenești și ovreești: „Acesta iaste împăratul jidovilor.” Iară un tîlhariu din cei răstigniți huliia pre dînsul, zicînd: „De ești tu H[risto]s, mîntuiaște-te pre tine și pre noi!”. Iară răspunzînd celalalt, l-au certat pre el, zicînd: „Nu te temi tu de D[u]mnezău, că întru aceaiaş osîndă ești? Și noi, cu direptul, căci ceale vreadnice după faptele noastre luom; iară acesta nice un rău n-au făcut." Și au zis lui I $[$ su $]$ s: „Pomeneaște-mă, $\mathrm{D}[\mathrm{oa}] \mathrm{mne}$, cînd vei veni întru împărățiia ta!”. Și au zis I[su]s lui: „Adevăr zicu 
astăzi cu mine vei fi în raiu." Și era ca la al șaselea ceas; și întunearec $f u$ preste tot pămîntul pînă la al noaolea ceas. Și să intunecă soarele și să rupse catapeteazma besearecii prin mijloc. Și, strigînd cu glas mare I[su]s, zise: „Părinte, în mîinile tale dau duhul mieu.” Și, aceastea zicînd, răposă. Iară văzînd sutaşul ce $f u$, slăvi pre D[u]mnezău, zicînd: „Adevărat, omul acesta dirept au fost!’. Și toată mulțimea carea venise împreună la privirea aceasta, văzînd cealea ce fură, bătîndu-ș, piepturile lor să întoarseră. Și sta toți cunoscuții lui de departe și muierile carele venisă după el din Galilea, văzînd aceastea. ție: astăzi împreună cu mine vei fi în rai." Și era ca la al șaselea ceas; și întunearec $s$-au făcut preste tot pămîntul pînă la al noaolea ceas. Și s-au intunecat soarele și s-au rupt catapeteazma besearecii prin mijloc. Și, strigînd cu glas mare I[su]s, au zis: „Părinte, în mîinile tale dau sufletul mieu." S,i, aceastea zicînd, au răpăosat. Iară văzînd sutașul cealea ce să făcuse, au slăvit pre $\mathrm{D}[\mathrm{u}] \mathrm{mnezău}$, zicind: „Cu adevărat, omul acesta dirept au fost!’. Și tot norodul ce fusease împreună la priveala aceaia, văzînd cealea ce să făcuse, bătîndu-ș piepturile sale, s-au întors. Și sta toți cunoscuții lui de departe și muierile carele venise după el din Galilea, văzînd aceastea.

În cele mai multe dintre situațiile care, în E 1693, prezintă construcții cu perfectul simplu surprinse în fragmentele de mai sus, s-a operat înlocuirea formei verbale cu cea de perfect compus-uneori cu opțiunea pentru un alt verb: puseră (E 1693, 264) - au aruncat $\left(\mathrm{E} 1697,122^{\mathrm{v}}\right), f u(\mathrm{E} 1693,265)$ - s-au făcut (E 1697 , $122^{v}$ ) -în realizarea E 1697. Acțiunea, cu gradul ei mare de consecvență, este caracteristică întregului text și face ca secvențele narative din E 1697, spre deosebire de E 1693, să aibă ca timp verbal prototipic perfectul compus.

Efortul de înlăturare a formelor de perfect simplu este, pe de o parte, în concordanță cu tendința semnalată, în general, pentru secolele XVII-XVIII, de restrîngere a ariei lui de circulație, în limba vorbită, la Oltenia, Banat și Crișana; pe de altă parte însă, contravine obişnuinței de a fi utilizat în continuare intens, în textele scrise (Frâncu, 2009, p. 306). Trecerea de la perfectul simplu la perfectul compus nu este o regulă generală și oarbă a diortosirii prezente, după cum se poate observa în două cazuri prezente în textele excerptate, unde perfectul simplu a fost înlocuit cu mai-mult-ca-perfectul, pentru redarea unui proces situat înaintea altui proces din trecut: $f u(\mathrm{E} 1693,265)$ - să făcuse (cu schimbare de număr, $\mathrm{E} 1697,122^{\mathrm{v}}$ ), fură $(\mathrm{E} 1693,265)$ - să făcuse $\left(\mathrm{E} 1697,123^{\mathrm{r}}\right)$. Diversitatea opțiunilor lingvistice în privința regimului timpurilor verbale de trecut, mai mare decît se înregistrează în ediția-bază, pune bine în evidență adîncimile temporale diferite ale narațiunii și ale planurilor discursive, percepute și controlate de diortositor. Lucrul acesta este mai evident în situațiile în care două forme de perfect simplu apropiate sau în succesiune imediată au rezolvări diferite în noua ediție, conform cu cronologia evenimentelor narate:

„văzînd sutașul ce fu, slăvi pre D[u]mnezău” (E 1693, 265) - „,ăzînd sutașul cealea ce să făcuse, au slăvit pre $\mathrm{D}[\mathrm{u}]$ mnezău" (E 1697, 123 ${ }^{\mathrm{r}}$ );

„Și toată mulțimea carea venise împreună la privirea aceasta, văzînd cealea ce fură, bătîndu-ș piepturile lor să întoarseră.” (E 1693, 265) - „Și tot norodul ce fusease împreună la priveala aceaia, văzînd cealea ce să facuse, bătîndu-ș piepturile sale, s-au întors." (E 1697, 123 ${ }^{\mathrm{r}}$ ).

Locurile în care forma de perfect simplu este păstrată sînt, prin comparaţie, mult mai rare.

\section{Variante tipografice}

Că ne aflăm în fața unei intenții programate de emendare a textului sub raport lingvistic este un fapt ce se descoperă nu doar în urma comparării edițiilor succesive ale cărții, ci și la cercetarea exemplarelor ediției din 1697, existente azi.

În Catalogul colectiv al cărții vechi românești (v. Evanghelie. Snagov, 1697) sînt înregistrate 11 exemplare. Dintre acestea, am putut compara amănunțit trei: un exemplar deținut de Biblioteca Academiei Române, București, inv. 467 (în continuare, pentru discuția privind diferențele lingvistice și tipografice dintre ele, E 1697 B); un exemplar deținut de Biblioteca Academiei Române, Iași, inv. n.a. (E 1697 I); 
și exemplarul aflat în Colecția de manuscrise și tipărituri vechi a Bibliotecii Naționale a Austriei, inv. 22.C.11 (E 1697 v). Cele trei exemplare nu sînt absolut identice: există între ele diferențe de natură tipografică, de grafie și lingvistice care indică desfășurarea unor etape în realizarea ediției. Diferențele ce privesc regimul timpurilor verbale, în speță, emendarea perfectului simplu din ediția-bază (E 1682/1693) se înregistrează în porțiuni de text tipărite pe f. $1^{\mathrm{r}-\mathrm{v}}$ şi $4^{\mathrm{r}-\mathrm{v}}$ :

E 1693 E 1697 I

\begin{tabular}{|c|c|c|}
\hline $\begin{array}{l}\text { Și lumina întru întunearec } \\
\text { luminează și întunearecul pre ia } n u \\
\text { o cuprinse. (1) }\end{array}$ & $\begin{array}{l}\text { Și lumina întru întunearec } \\
\text { luminează și întunearecul nu o } \\
\text { cuprinse. }\left(1^{\mathrm{r}} / 1\right)\end{array}$ & $\begin{array}{l}\text { Și lumina întru întunearec } \\
\text { luminează și întunearecul nu o au } \\
\text { cuprins. }\left(1^{\mathrm{r}} / 1\right)\end{array}$ \\
\hline $\begin{array}{l}\text { Că leagea prin Moisii fu dată, iară } \\
\text { darul pren } I[\text { su }] s ~ H[\text { risto]s } f u . ~(2)\end{array}$ & $\begin{array}{l}\text { Că leagea prin Moisii au fost dată, } \\
\text { iară darul și adevărul prin } \mathrm{I}[\mathrm{su}] \mathrm{s} \\
\mathrm{H}[\text { risto }] \mathrm{s} f \mathrm{.}\left(\mathrm{1}^{\mathrm{v}} / 1\right)\end{array}$ & $\begin{array}{l}\text { Că leagea prin Moisii au fost dată, } \\
\text { iară darul și adevărul prin I }[\mathrm{su}] \mathrm{s} \\
\mathrm{H}[\text { risto }] \text { s au fost. }\left(1^{\mathrm{v}} / 1\right)\end{array}$ \\
\hline $\begin{array}{l}\text { Și-l întrebară: „Dară Cine ești? Au } \\
\text { doară tu ești Ilie?” (3) }\end{array}$ & $\begin{array}{l}\text { Și-l întrebară: „Cine ești? Au doară } \\
\text { tu ești Ilie?” }\left(1^{\mathrm{v}} / 2\right)\end{array}$ & $\begin{array}{l}\text { Și l-au întrebat: „Cine ești ? Au } \\
\text { doară tu ești Ilie?” (1 } 1 \text { /2) }\end{array}$ \\
\hline Deci ziseră lui: „Cine ești?...” (3) & $\begin{array}{l}\text { Deci ziseră lui: „Cine ești?...” } \\
\left(1^{\mathrm{v}} / 2\right)\end{array}$ & $\begin{array}{l}\text { Deci au zis lui: „Cine ești?...” } \\
\left(1^{\mathrm{v}} / 2\right)\end{array}$ \\
\hline $\begin{array}{l}\text { Deci cînd să sculă din morți ș-au } \\
\text { adus aminte ucenicii lui că aceasta } \\
\text { zicea lor și crezură scripturii și } \\
\text { cuvîntului carele zisease I[su]s. (7) }\end{array}$ & $\begin{array}{l}\text { Deci cînd să sculă den morți ș-au } \\
\text { adus aminte ucenicii că aceasta } \\
\text { zicea lor și crezură scripturii şi } \\
\text { cuvîntului carele zisease I }[\mathrm{su}] \mathrm{s} \text {. } \\
\left(3^{\mathrm{v}} / 2-4^{\mathrm{r}} / 1\right)\end{array}$ & $\begin{array}{l}\text { Deci cînd să sculă den morți ş-au } \\
\text { adus aminte uc[e]nicii că aceasta } \\
\text { zicea lor şi au crezut scripturii și } \\
\text { cuvîntului carele zisease I }[\mathrm{su}] \text { s. } \\
\left(3^{\mathrm{v}} / 2-4^{\mathrm{r}} / 1\right)\end{array}$ \\
\hline Și să bucurară uc[e]nicii văzînd pre & Și să bucurară ucenicii văzînd pre & Și s-au bucurat ucenicii văzînd pre \\
\hline $\mathrm{D}[\mathrm{o}] \mathrm{mnul}(8)$ & Domnul $\left(4^{r} / 2\right)$ & Domnul $\left(4^{\mathrm{r}} / 2\right)$ \\
\hline Iară Thoma, unul din cei & Iară Thoma, unul den cei & Iară Thoma, unul den cei \\
\hline doisprăzeace, care să chiamă & doisprăzeace, care să chiamă & doisprăzeace, care să chiamă \\
\hline Geamăn, nu era cu ei cînd veni & Geamăn, nu era cu ei cînd veni & Geamăn, nu era cu ei cînd au venit \\
\hline $\mathrm{I}[\mathrm{su}] \mathrm{s.}(8)$ & $\mathrm{I}[\mathrm{su}] \mathrm{s} .\left(4^{\mathrm{v}} / 1\right)$ & $\mathrm{I}[\mathrm{su}] \mathrm{s} .\left(4^{\mathrm{v}} / 1\right)$ \\
\hline $\begin{array}{l}\text { Iară el zise lor: „De nu voiu } \\
\text { vedea...” (8) }\end{array}$ & $\begin{array}{l}\text { Iară el zise lor: „De nu voiu } \\
\text { vedea...” }\left(4^{\mathrm{v}} / 1\right)\end{array}$ & $\begin{array}{l}\text { Iară el le-au zis lor: „De nu voiu } \\
\text { vedea...” }\left(4^{\mathrm{v}} / 1\right)\end{array}$ \\
\hline $\begin{array}{l}\text { Zise lui I[su]s: „Deaca mă văzuși, } \\
\text { crezuşi...” (9) }\end{array}$ & $\begin{array}{l}\text { Zise lui I }[\mathrm{su}] \mathrm{s}: \text { „Deaca mă văzuși, } \\
\text { crezuși...” }\left(4^{\mathrm{v}} / 1\right)\end{array}$ & $\begin{array}{l}\text { Zis-au I[su]s lui: „Deaca mă văzuși, } \\
\text { Thomo, crezuși...” }\left(4^{\mathrm{v}} / 1\right)\end{array}$ \\
\hline $\begin{array}{l}\text { În vreamea aceaia nuntă să făcu în } \\
\text { Cana Galileii ( } 9 \text { ) }\end{array}$ & $\begin{array}{l}\text { În vreamea aceaia nuntă să făcu în } \\
\text { Cana Galileii }\left(4^{\mathrm{v}} / 2\right)\end{array}$ & $\begin{array}{l}\text { În vreamea aceaia nuntă } s \text {-au făcut } \\
\text { în Cana Galileii }\left(4^{v} / 2\right)\end{array}$ \\
\hline Și-i aduseră (9) & Și-i aduseră $\left(4^{\mathrm{v}} / 2\right)$ & Și i-au adus. $\left(4^{\mathrm{v}} / 2\right)$ \\
\hline $\begin{array}{l}\text { după ce gustă nunul apa ce să făcuse } \\
\text { vin (9) }\end{array}$ & $\begin{array}{l}\text { după ce gustă nunul apa ce să făcuse } \\
\text { vin }\left(4^{\mathrm{v}} / 2\right)\end{array}$ & $\begin{array}{l}\text { după ce au gustat nunul apa ce să } \\
\text { făcuse vin }\left(4^{v} / 2\right)\end{array}$ \\
\hline
\end{tabular}

Aparținînd ediției E 1697, exemplarul E 1697 I înregistrează, după cum am arătat mai sus, puternica tendință de emendare a formelor din paradigma trecutului verbal; însă prezintă o serie de forme de perfect simplu care nu apar în E 1697 v și E 1697 B, dar care corespund formelor din ediţia-bază, în locurile respective. Este posibil ca, lucrînd asupra textului, diortositorul / tipograful să fi operat un prim val de modificări, imprimînd în consecință foaia tipografică cu o formă a textului vizibilă în E 1697 I; la o reevaluare a ceea ce se lucrase pînă atunci, probabil sub influența unei din ce în ce mai clare convingeri în privința justeții acestei practici emendatorii, editorul revine asupra textului, îl corectează suplimentar în zaț (ori reconstruiește pagina) și reimprimă în consecință foaia tipografică cu o formă a textului vizibilă în E 1697 V și E 1697 B; și continuă apoi într-o manieră care, pînă la sfirșit, îl satisface în privința aspectului lingvistic, nerevenind la text pentru corectări pe foile tipografice care ajung să constituie restul cărții.

Alte diferențe lingvistice în locuri corespondente, care pun în contrast E $1697 \mathrm{I}^{3} \mathrm{cu}$,grupul” E $1697 \mathrm{~V}$

${ }^{3}$ De mai multe ori, formele la care ne referim aici se regăsesc în versiunile editate anterior ale cărții. Cîteva însă $\left(\operatorname{din}, 1^{\mathrm{v}} / 1\right.$; sfîrşîndu-se, 4v /2) reprezintă emendări față de E 1693 și/sau E 1682. Faptul că aceste emendări nu mai apar în E 1697 V și B nu 
și B, sînt:

E 1693

E 1697 I

Е $1697 \mathrm{~V} / \mathrm{B}$

\begin{tabular}{|c|c|c|}
\hline întru una de simbete (2) & întru una din simbete $\left(1^{\mathrm{v}} / 1\right)$ & întru una de simbete $\left(1^{\mathrm{v}} / 1\right)$ \\
\hline$\overline{\text { Priimiți D[u]h Sf[î]nt (2) }}$ & Priimiţi D[u]hul Sf $[\hat{1}] \mathrm{nt}\left(1^{\mathrm{r}} / 1\right)$ & Luaț D[u]hul Sf[1̂] nt (1r/1) \\
\hline $\begin{array}{l}\text { De nu voiu vedea în mîinile lui } \\
\text { ranele piroanelor și să puiu deagetul } \\
\text { mieu în ranele piroanelor }(2)\end{array}$ & $\begin{array}{l}\text { De nu voiu vedea în mîinile lui } \\
\text { ranele piroanelor și de nu voiu băga } \\
\text { deagetul mieu în ranele piroanelor } \\
\left(1^{\mathrm{v}} / 1\right)\end{array}$ & $\begin{array}{l}\text { De nu voiu vedea în mîinile lui } \\
\text { ranele cuielor și de nu voiu băga } \\
\text { deagetul mieu în ranele cuielor } \\
\left(1^{\mathrm{V}} / 1\right)\end{array}$ \\
\hline $\begin{array}{l}\text { Pre } \mathrm{D}[\mathrm{u}] \text { mnezău nime nu l-au } \\
\text { văzut }(2)\end{array}$ & $\begin{array}{l}\text { Pre } \mathrm{D}[\mathrm{u}] \text { mnezău nime nu l-au } \\
\text { văzut }\left(1^{\mathrm{v}} / 2\right)\end{array}$ & $\begin{array}{l}\text { Pre } \mathrm{D}[\mathrm{u}] \text { mnezău nimenea nu l-au } \\
\text { văzut }\left(1^{\mathrm{v}} / 2\right)\end{array}$ \\
\hline arătă lor mîinele și coasta lui (8) & $\begin{array}{l}\text { le-au arătat lor mîinele și coasta sa } \\
\left(4^{\mathrm{r}} / 2\right)\end{array}$ & $\begin{array}{l}\text { le-au arătat lor mîinile și coasta sa } \\
\left(4^{\mathrm{r}} / 2\right)\end{array}$ \\
\hline$\overline{\text { Luați } D[u] h \text { Sf[1̂] nt (8) }}$ & Luați $D[u] h$ Sf[î̀nt $\left(4^{\mathrm{v}} / 1\right)$ & Luaţi $D[u] b u l ~ S f[\hat{1}] \mathrm{nt}\left(4^{\mathrm{v}} / 1\right)$ \\
\hline $\begin{array}{l}\text { De nu voiu vedea în mîinele lui } \\
\text { ranele (8) }\end{array}$ & $\begin{array}{l}\text { De nu voiu vedea în mîinele lui } \\
\text { ranele }\left(4^{\mathrm{v}} / 1\right)\end{array}$ & $\begin{array}{l}\text { De nu voiu vedea în mîinile lui } \\
\text { ranele }\left(4^{\mathrm{v}} / 1\right)\end{array}$ \\
\hline vezi mîinele meale (9) & vezi mîinele meale $\left(4^{\mathrm{v}} / 1\right)$ & vezi mîinile meale $\left(4^{\mathrm{v}} / 1\right)$ \\
\hline Deaca mă văzuși, / / crezuși (9) & Deaca mă văzuși, / / crezuși ( $\left.4^{\mathrm{v}} / 1\right)$ & $\begin{array}{l}\text { Deaca mă văzuși, Thomo, crezuși } \\
\left(4^{\mathrm{v}} / 1\right)\end{array}$ \\
\hline $\begin{array}{l}\text { au făcut } \mathrm{I}[\mathrm{su}] \mathrm{s} \mathrm{şi} \mathrm{alte} \mathrm{seamne} \mathrm{multe} \\
\text { înaintea ucenicilor lui }(9)\end{array}$ & $\begin{array}{l}\text { au făcut I[su]s și alte seamne multe } \\
\text { înaintea uc[e]nicilor } l u i\left(4^{\mathrm{v}} / 1\right)\end{array}$ & $\begin{array}{l}\text { au făcut } \mathrm{I}[\mathrm{su}] \mathrm{s} s, i \text { alte seamne multe } \\
\text { înaintea ucenicilor } s a ̆ i\left(4^{\mathrm{v}} / 1\right)\end{array}$ \\
\hline $\begin{array}{l}\text { care nu s-au scris în cartea aceasta } \\
(9)\end{array}$ & $\begin{array}{l}\text { care nu s-au scris în cartea aceasta } \\
\left(4^{\mathrm{v}} / 1\right)\end{array}$ & $\begin{array}{l}\text { carele nu s-au scris în cartea aceasta } \\
\left(4^{\mathrm{v}} / 1\right)\end{array}$ \\
\hline sfirșindu-se v & sfîrșindu-se vinul & sfirşsindu-se vinul $\left(4^{\mathrm{v}} / 2\right)$ \\
\hline
\end{tabular}

Aceste diferențe de ordin fonetic și gramatical sînt însoțite pe aceleași coli de modificări mai mici, de natură tipografică și grafică, fără repercusiuni la alte niveluri de limbă ${ }^{4}$ :

a) utilizarea unui model diferit de slovă:

\begin{tabular}{|c|c|}
\hline E 1697 I & E $1697 \mathrm{~V} / \mathrm{B}$ \\
\hline त̈рнгї $\left(1^{\mathrm{v}} / 1, \mathrm{r} .1\right)$ & етрнгі $\left(1^{\mathrm{v}} / 1, \mathrm{r} .1\right)$ \\
\hline ઠуп̈нтїн $\left(4^{\mathrm{r}} / 1, \mathrm{r} .8\right)$ & 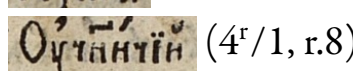 \\
\hline Líwa $\left(4^{\mathrm{r}} / 2, \mathrm{r} .20\right)$ & 3íwa $\left(4^{\mathrm{r}} / 2, \mathrm{r} .20\right)$ \\
\hline
\end{tabular}

b) utilizarea unei slove diferite (unui semn diacritic) dar cu aceeași valoare fonetică:

E 1697 I

E $1697 \mathrm{~V} / \mathrm{B}$

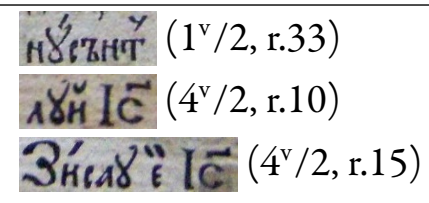

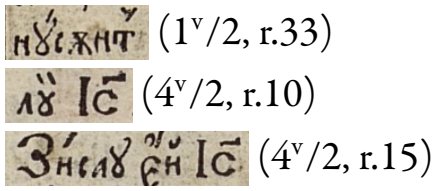

c) cuvint întreg $v s$. prescurtare/slovă scrisă deasupra rîndului:
E 1697 I
E 1697 V/B
Móna 8 (1 $12, \mathrm{r} .20)$
Nit $3 \hat{H}\left(4^{\mathrm{r}} / 2, \mathrm{r} .26\right)$

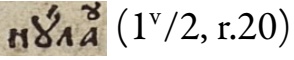
1 เ8 зйек $\left(4^{\mathrm{r}} / 2, \mathrm{r} .26\right)$

înseamnă neapărat o revenire propriu-zisă a diortositorului la modelul E 1693 sau E 1682, în timpul reluării lucrului la primele foi tipografice, ci poate fi o simplă (re)evaluare a expresiei sub inflențe care nu au nimic de-a face cu autoritatea ediţiei-bază.

${ }^{4} S, i$ aici, și mai jos, dăm numai cîteva exemple din fiecare categorie depistată; diferențele notate vizează locuri tipografice absolut corespondente. 
d) organizare tipografică a rîndului diferită:

\begin{tabular}{|c|c|}
\hline E 1697 I & E 1697 V/B \\
\hline 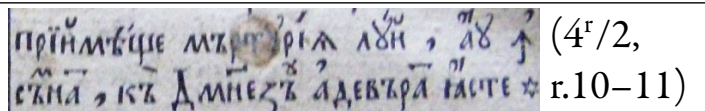 & 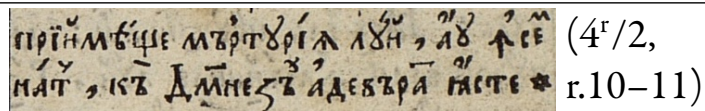 \\
\hline
\end{tabular}

e) diferențe în implicarea semnelor diacritice și/sau a semnelor grafice fără valoare fonetică:

\begin{tabular}{|c|c|}
\hline E 1697 I & E $1697 \mathrm{~V} / \mathrm{B}$ \\
\hline $\sin A^{\prime} \operatorname{siT}^{\mathrm{y}}\left(1^{\mathrm{v}} / 1, \mathrm{r} .7\right)$ & 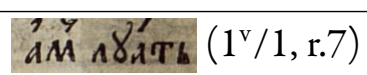 \\
\hline фіния $\left(1^{\mathrm{v}} / 1, \mathrm{r} .19\right)$ & 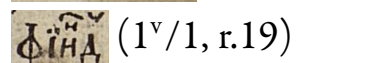 \\
\hline
\end{tabular}

În final, în legarea cărții sînt folosite toate variantele tipografice ale textului, ceea ce determină apariția și punerea în circulație a unor exemplare distincte ${ }^{5}$.

Faptul că modificările nu privesc întreaga realizare tipografică (pot fi observate, indiferent de natura lor-v. și infra-, pînă la f. $7^{\mathrm{r}}$ ) ne determină să considerăm neîntemeiată introducerea în discuție, pentru ediția E 1697, noțiunile de tiraj inițial, căruia i-ar aparține E 1697 I (probabil și altele), și de al doilea tiraj etc., căruia/cărora i-ar aparține alte exemplare. Este cert însă că obiectele E 1697 I, E 1697 V şi E 1697 B, apărute în urma activităţii tipografice în totalitate, reflectă momente distincte în procesul de editare a textului.

Cele indicate pînă acum plasează executarea filelor $1^{\mathrm{r}-\mathrm{v}}$ și $4^{\mathrm{r}-\mathrm{v}}$ ale exemplarului E 1697 I în anterioritatea celei a filelor corespondente din E 1697 v și в. Conjectura cronologică trebuie însă modificată pentru filele $2^{\mathrm{r}-\mathrm{v}}$ și $3^{\mathrm{r}-\mathrm{v}}$, unde diferențele pun în opoziție exemplarul E $1697 \mathrm{v}$ față de exemplarele E 1697 I și B. Și aici, acestea sînt mai degrabă tipografice și de grafie:

a) utilizarea unui model diferit de slovă:

\begin{tabular}{|c|c|}
\hline E 1697 V & E 1697 I/B \\
\hline ä) उнंє $\left(2^{r} / 1, r .6\right)$ & 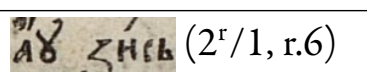 \\
\hline AÝecta $\left(2^{\mathrm{r}} / 2, \mathrm{r} .31\right)$ & ลั'́์ีa $\left(2^{\mathrm{r}} / 2, \mathrm{r} .31\right)$ \\
\hline 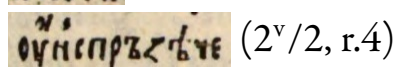 & 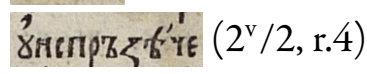 \\
\hline
\end{tabular}

b) utilizarea unei slove diferite dar cu aceeași valoare fonetică:

\begin{tabular}{|c|c|}
\hline E $1697 \mathrm{~V}$ & E 1697 I/B \\
\hline Áapz $\left(2^{\mathrm{r}} / 1, \mathrm{r} .9\right)$ & $A_{1}$ APb $\left(2^{r} / 1\right.$, r.9) \\
\hline उस्YE $\left(2^{r} / 1, r .2\right)$ & зйчн $\left(2^{\mathrm{r}} / 1, \mathrm{r} .2\right)$ \\
\hline мв хниццн $\left(2^{\mathrm{r}} / 2, \mathrm{r} .14\right)$ & мх хни́цн $\left(2^{\mathrm{r}} / 2, \mathrm{r} .14\right)$ \\
\hline спимахнтА $\left(2^{\mathrm{v}} / 1, \mathrm{r} .1\right)$ & 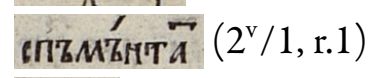 \\
\hline Shíwa $\left(2^{\mathrm{v}} / 1, \mathrm{r} .24\right)$ & కíwa $\left(2^{\mathrm{v}} / 1, \mathrm{r} .24\right)$ \\
\hline
\end{tabular}

c) cuvînt întreg $v$ s. prescurtare/slovă scrisă deasupra rîndului:

\begin{tabular}{|c|c|}
\hline E $1697 \mathrm{~V}$ & E 1697 I/B \\
\hline$\Pi_{\text {роро́кனив }}\left(2^{\mathrm{r}} / 1, \mathrm{r} .6\right)$ & $\Pi_{\text {pprs }}^{\hat{a}} \gamma_{1 b}\left(2^{r} / 1, \mathrm{r} .6\right)$ \\
\hline 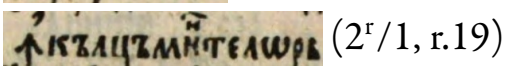 & 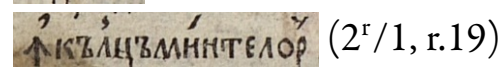 \\
\hline мормй̛т $\left(2^{v} / 1, r .2\right)$ & 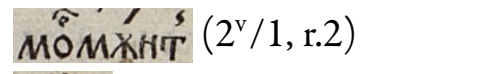 \\
\hline กх́хинЕ $\left(2^{\mathrm{v}} / 1, \mathrm{r} .27\right)$ & пाँ̈KE $\left(2^{\mathrm{v}} / 1, \mathrm{r} .27\right)$ \\
\hline
\end{tabular}

d) organizare tipografică a rîndului diferită:

\footnotetext{
${ }^{5}$ Scopurile avute în vedere în privința cercetării operei lui Antim Ivireanul (sau a unor problematici mai largi) nu au dus la evidențierea, pînă acum, a acestui fapt: v. BRV I, loc. cit.; Ștrempel (1997); Chițulescu (2016) etc.
} 
E $1697 \mathrm{~V} \quad$ E 1697 I/B

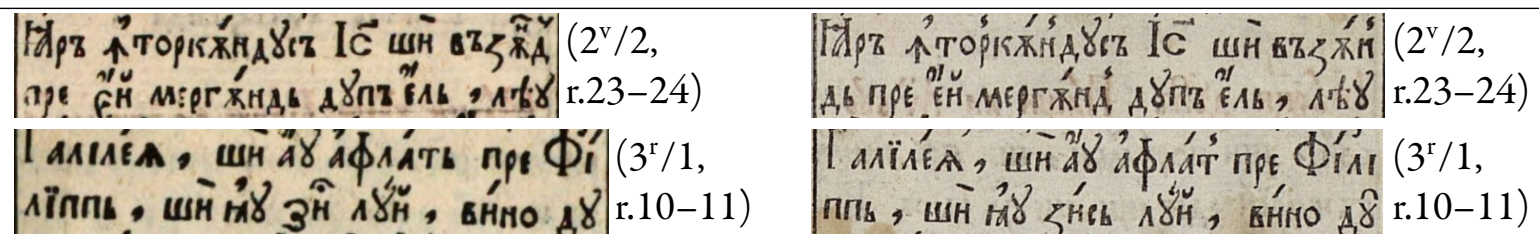

e) diferențe în implicarea semnelor diacritice și/sau a semnelor grafice fără valoare fonetică:

\begin{tabular}{|c|c|}
\hline E $1697 \mathrm{~V}$ & E 1697 I/B \\
\hline 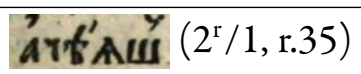 & '́rt'Aus $\left(2^{\mathrm{r}} / 1, \mathrm{r} .35\right)$ \\
\hline депа́рт $\left(2^{\mathrm{r}} / 2, \mathrm{r} .1\right)$ & Aєпарте $\left(2^{\mathrm{r}} / 2, \mathrm{r} .1\right)$ \\
\hline ov $^{x_{\mathrm{H}}}\left(2^{\mathrm{r}} / 2, \mathrm{r} .17\right)$ & คิท $\left(2^{\mathrm{r}} / 2, \mathrm{r} .17\right)$ \\
\hline
\end{tabular}

În afară de acest tip de modificări operate la un moment dat, există și cîteva-mult mai puține-care vizează uzul propriu-zis al limbii la alt nivel: este vorba de forme fonetice diferite ale aceleiași unități lingvistice:

\begin{tabular}{ll}
\multicolumn{1}{c}{ E $1697 \mathrm{v}$} & \multicolumn{1}{c}{$\mathrm{E} 1697 \mathrm{I} / \mathrm{B}$} \\
\hline sculindu-se $\left(2^{\mathrm{r}} / 1, \mathrm{r} .29\right)$ & sculindu-s $\breve{a}\left(2^{\mathrm{r}} / 1, \mathrm{r} .29\right)$ \\
Isaia $\left(2^{\mathrm{r}} / 1, \mathrm{r} .6\right)$ & Isaiia $\left(2^{\mathrm{r}} / 1, \mathrm{r} .6\right)$ \\
luund $\left(2^{\mathrm{v}} / 1, \mathrm{r} .27\right)$ & luînd $\left(2^{\mathrm{v}} / 1, \mathrm{r} .27\right)$
\end{tabular}

În sfirșit, la $7^{\mathrm{r}}$, trei forme grupează exemplarele E 1697 I și v, pe de o parte, și E 1697 B, pe de altă parte:

\begin{tabular}{ll}
\multicolumn{1}{c}{$\mathrm{E} 1697 \mathrm{I} / \mathrm{v}$} & \multicolumn{1}{c}{$\mathrm{E} 1697$ в } \\
\hline văşmînt $\left(7^{\mathrm{r}} / 1, \mathrm{r} .4\right)$ & veșmînt $\left(7^{\mathrm{r}} / 1, \mathrm{r} .4\right)$ \\
nimănui $\left(7^{\mathrm{r}} / 1, \mathrm{r} .18\right)$ & nimunui $\left(7^{\mathrm{r}} / 1, \mathrm{r} .18\right)$ \\
$\operatorname{sămn}\left(7^{\mathrm{r}} / 2, \mathrm{r} .18\right)$ & $\operatorname{semn}\left(7^{\mathrm{r}} / 2, \mathrm{r} .18\right)$
\end{tabular}

Dacă cele observate arată clar un proces de revenire în mai multe etape asupra editării textului, rămîn totuşi neclare motivațiile acesteia în unele dintre situațiile expuse mai sus. În procesul tipăririi ediției din 1697 se ajunge să se refacă șpalturile pentru filele $2^{\mathrm{r}-\mathrm{v}}$ și $3^{\mathrm{r}-\mathrm{v}}$, bunăoară, însă natura și numărul modificărilor rezultate nu indică o orientare determinată de judecata asupra aspectului lingvistic al textului, cum se întîmplă—credem—în situația modificărilor ce țin de gramatica verbului.

\section{Concluzii}

Indiferent de cauzele reluării lucrului asupra unor porțiuni oarecare din text, existența variantelor tipografice, valorificate în realizarea finală a Evangheliei de la Snagov, din 1697, pune în lumină un comportament editorial și tipografic complex și neliniar.

Existența diferențelor între exemplare, de orice tip, înseamnă și că rezultatele cercetării textului strict în vederea descrierii lingvistice a acestuia vor varia — chiar dacă într-o măsură care poate fi apreciată ca micăîn funcție de exemplarul ales (eventual, întîmplător) ca obiect de studiu. Pe de altă parte însă, tocmai practica emendării repetate a obiectului tipografic in situ oferă lingvistului modern şansa de a percepe nu limba textului, ci limba care scrie textul, emanată de conștiința cuiva, care în felul acesta, indirect, își dezvăluie judecata aplicată asupra a ceea ce este în acord cu obişnuințele lingvistice ale epocii și ale locului. 


\section{Bibliografie}

\section{A. Surse}

E 1682 = Sfinta și dumnezăiasca Evanghelie, București.

E 1693 = Evanghelie greco-română, București.

E $1697=$ Sf[î] nta şi $d[u]$ mnezeiasca Evanghelie, Snagov.

\section{B. Lucrări de referință}

BRV I = Bianu, I. \& Hodoș, N. (1903). Bibliografia românéscă veche. 1508-1830. Tomul I, 1508-1716, Stabilimentul grafic

J.V. Socec, Bucuresci, 1903.

Chițulescu, P. (coord.) (2016). Antim Ivireanul. Opera tipografică, Institutul Cultural Român, [s.l.].

Frâncu, C. (2009). Gramatica limbii române vechi (1532-1780), Casa Editorială „Demiurg”, Iași.

Iova, M. (coord.). Catalogul colectiv al cărții românești vechi, Evanghelie. Snagov, 1697.

Pavel, E. (2012). Arheologia textului, Casa Cărții de Știință, Cluj-Napoca.

Ștrempel, G. (1997). Antim Ivireanul, Editura Academiei, București. 